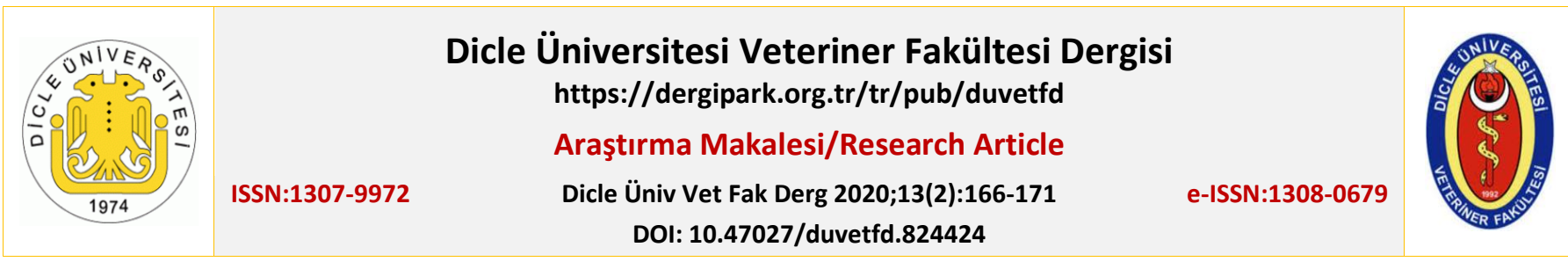

\title{
Sıçanların Meme Dokusunda Gebelik, Laktasyon ve İnvolusyon Periyodları Süresince Ghrelin, Obestatin ve Leptin Dağılımı
}

\author{
Berna GÜNEY SARUHAN ${ }^{1, a, 凶}$, Hakan SAĞSÖZ ${ }^{1, b}$, Uğur TOPALOĞLU ${ }^{1, c}$
}

${ }^{1}$ Dicle Üniversitesi, Veteriner Fakültesi, Histoloji-Embriyoloji Anabilim Dalı, Diyarbakır, TÜRKiYE

aORCID: 0000-0002-5111-5424; 'ORCID: 0000-0002-5456-697X; 'CORCID: 0000-0002-8306-491X

\begin{tabular}{ccc}
\hline Geliş Tarihi/Received & Kabul Tarihi/Accepted & Yayın Tarihi/Published \\
20.11 .2020 & 23.12 .2020 & 31.12 .2020 \\
\hline
\end{tabular}

Öz

Memeli yavruları için süt önemli bir besin kaynağıdır. Süt üretiminde ve salınımında önemli rol oynayan memede bu bakımdan önemli bir organdır. Bu çalışmada, immünohistokimyasal boyama ile ratların meme bezinde peptit hormonları olan leptin, ghrelin ve obestatin ekspresyonu ve lokalizasyonunun gösterilmesi amaçlanmıştır. Bu amaçla, çalışmada 35 adet erişkin dişi sıçanlar kullanılmıştır. Alveol ve kanal epitel hücrelerinde ghrelin immunreaksiyonunun, gebeliğin 1. döneminde zayıf, gebeliğin 2. ve 3. dönemleri ile laktasyon periyodunda güçlü, involüsyon periyodunda ise zayıf olduğu tespit edilmiştir. Obestatin immunreaksiyonun, gebeliğin tüm dönem lerinde ve laktasyon periyodunda alveol ve kanal epitel hücrelerinde güçlü olduğu, involüsyon periyodunda ise zayıfladığı görülmüştür. Leptinin tüm periyodlarda güçlü bir immunreaksiyon gösterdiği belirlenmiştir. Bağdoku (özellikle yağ hücreleri) ve miyoepitel hücrelerinde obestatin ve leptinin orta yoğunlukta bir immunreaksiyon gösterdiği oraya konulmuştur. Sonuç olarak, sıçan meme bezinin aktif dönemde ghrelin, obestatin ve leptin için önemli bir kaynak oluşturduğunu ileri sürebiliriz.

Anahtar Kelimeler: Ghrelin, leptin, involüsyon, gebelik, obestatin

Distribution of Ghrelin, Obestatin and Leptin in the Mammary Gland of Rats During the Periods of Pregnancy, Lactation and Involution

\section{Abstract}

Milk is an important food source for mammal youngs. Udder, which play an important role in milk production and release, are important organs in this respect. In this study, we aimed to show the localization and expression of the peptide hormones leptin, ghrelin and obestatin by immunohistochemical method in udder tissue. For this purpose, 35 adult female were used in the study. It was observed that Ghrelin immunoreactivity, which was weak in the first period of pregnancy in the alveolar and duct epithelium, increased in the 2 nd and 3rd periods of the staining, became stronger during the lactation period and decreased in the involution. In staining with obestatin, intense staining was observed in alveoli and canal epithelium in all periods of pregnancy and lactation period, while it was observed to decrease in involution. A strong staining was observed in all periods in leptin immunoreactivity. Moderate staining with obestatin and leptin was detected in adipose, connective tissue and myoepithelial cells. As a result, we can say that the mammary gland is an important source of ghrelin, obestatin and leptin in active period.

Key Words: Ghrelin, leptin, involution, pregnancy, obestatin

\section{Giriş}

Canlıların beslenmesinde büyük önem taşıyan sütün sağlıklı ve nitelikli olması, üretildiği yer olan memenin sağlığı ile yakından ilgilidir (1). Memenin makro- ve mikroanatomisi hayat boyunca farklı özellikler sergiler. Meme bezi, şekli, büyüklüğü ile gebelik, laktasyon ve involüsyon periyodlarında büyüme ve farklılaşma gibi yapısal değişimlere uğrayan bir organ olarak karşımıza çıkar (2-4). Tüm canlılarda, uygun besin maddelerinin belirlemesi, metabolizma olaylarının düzenlenmesi, vücut ağırlığının ve enerji dengesinin (embriyonal gelişim, çocukluk ve yetişkinlik dönemleri) devamlılığının sağlanması önemlidir. Yukarıda bahsedilen ve tüm canlılar için hayati öneme sahip olan bu olaylar zinciri de birçok moleküler proteinler ile hormonlar tarafından (leptin, gherilin v.b.) düzenlenmektedir ve bu faktörler arasında da oldukça güçlü bağlar olduğu açıkça görülmektedir $(5,6)$. Bunlardan, leptin memelilerde gıda maddelerinin tüketiminin kontrolünde, beslenme adaptasyonunun sağlanmasında, enerji homeostazisinin ve yağ depolarını düzenlemesinde önemli roller oynarken, aynı preproghrelin (ppGHREL) geni tarafından kodlanan ghrelin ve obestatin ise, gıda alımı ve vücut ağırlığının düzenlenmesinde rol oynar $(5,7)$.

Ghrelin temel olarak mide fundusundan salgılanan 28 aminoasitlik lipopeptid yapıda bir hormondur. Bu hormon ayrıca hipotalamus, hipofiz, tükürük bezi, tiroid bezi, ince barsak, böbrekler, kalp, merkezi sinir sistemi, akciğer, plasenta, gonadlar, meme ve dişlerde de sentezlenmektedir (8). Anne sütünün içerdiği ghrelin meme bezi tarafından üretilmektedir (5). Ghrelin, enerji dengesi üzerine en büyük etkiye 
sahip olduğu düşünülen hormonlardan biridir ve bundan dolayı da fizyolojik fonksiyonu üzerine çeşitli çalışmalar yapılmıştır $(9,10)$. Büyüme hormonunun endojen salıcısı olan ghrelin'nin, meme bezinde ghrelin/büyüme hormonu salgılatıcı reseptörü (GHS-R) ekseninde otokrin/parakrin etkileşimler yolu ile kanser hücrelerinin büyümesine etki ederek bazı kanser tiplerinin şekillenmesinde de etkili olabileceği vurgulanmıştır $(11,12)$.

Obestatin anorektik bir peptid olup, ghrelin hormonu ile aynı gen tarafından kodlanmaktadır. Mide, ince barsak, hipotalamus ve hipofiz gibi birçok dokuda üretilmektedir. Obestatin ghrelinle ilişkili bir peptid olup ghreline karşı zıt etki göstermektedir. Ancak, ghrelin ile obestatin hakkında yapılan ilk çalışmalar da her ne kadar bu iki peptit hormonu arasında zıt bir etkileşim olduğu ileri sürse de obsetatin/ghrelin ilişkisi halen çok net değildir (8). Son yıllardaki çaIışmalar, obestatinin enerji harcamasının kontrolü ve vucütta metabolizmanın düzenlenmesindeki rolünün hala tartışmalı olduğunu bildirmektedir (13).

Leptos kelimesinden türetilen ve yunanca da ince zayıf anlamına gelen leptin, yağ doku kökenli sinyal faktörü olarak ilk kez Zhang ve ark. (14) tarafından tanımlanmıştır. Son yıllarda leptinin sentezi, salgılanması, reseptörleri ve etkileri üzerine birçok çalışma yapılmıştır. Bu çalışmalarda leptinin; iştah, açlık, enerji harcanmasının düzenlenmesi ile üreme üzerinde etkili olduğu gösterilmiştir $(5,6,14,15,16)$. Yapılan bu çalışmalarda, enerji metabolizmasının düzenlenmesinde leptinin, ghrelin ile birlikte merkezi sinir sistemindeki özel nöronları etkileyerek rol oynadığı ileri sürülmektedir $(5,6,14,15)$. Ayrıca ghrelinin de leptinin tersine iştah ve yağ miktarını artırıcı özelliklere sahip olduğu bildirilmektedir (15).

Daha önce, sıçanlarda $(10)$ ve insanlarda $(7,16)$ hem laktasyon döneminki meme bezinde hem de süt içinde ghrelin, obestatin ve leptinin ekspresyonları ve varlığı araştırılmıştır. Buna karşın sıçanlarda meme dokusunda gebelik, laktasyon ve involüsyon periyodlarında bu hormonların lokalizasyonları, dağılımları ve birbirleriyle olan ilişkilerini gösteren çalışmalar mevcut değildir. Bu nedenle çalışmamızda, sıçanlarda gebelik, laktasyon ve involüsyon periyodlarında; meme bezinin histolojik yapısında meydana gelen değişikliklere bağlı olarak bu peptit hormonların dağılımlarının ve yerleşimlerinin nasıl olabileceği sorusunun açıklanması hedeflenmektedir. Özellikle, meme alveol ve kanal epitelinde, yağ, bağ dokusu ve miyoepitel hücrelerindeki yerleşimleri immunohistokimyasal olarak belirlenerek, ekspresyon yoğunluklarına göre semi-kantitatif analizleri yapılacaktır. Ayrıca, daha önce yapılmış olan çalışmalar ışığında, sıçan meme bezinde leptin, gherilin ve obestatinin lokalize ya da ekspresse olduğu hücrelere göre olası fizyolojik rolleri ortaya konulacaktır.

\section{MATERYAL VE METOT}

\section{Numunelerin Toplanması ve Tespit İşlemi}

Çalışmada, Dicle Üniversitesi Prof. Dr. Sabahattin PAYZIN Sağlık Bilimleri Araştırma ve Uygulama Merkezi (DÜSAM) Müdürlüğü'nden temin edilen 35 adet erişkin, 220-250 gr ağırlığında Spraque-Dawley ırkı dişi sıçanlar kullanıldı (ÇaIışma Dicle Üniversitesi Deney Hayvanları Yerel Etik Kurulu (DÜHADEK) tarafından onaylanmıştır (Karar sayısı 2008-02). Hayvanlar, deney süresince 12 saat aydınlık ve 12 saat karanlık ışık ortamında barındırıldı. Pelet yem ve su ihtiyaçları ad libitum olarak karşılandı. Her grupta 7 hayvan olacak şekilde rastgele 5 gruba oluşturuldu. Her gruptaki dişiler iki erkek sıçanla çiftleşmeye alındı. Vaginal smear metoduyla gebelik muayenesi yapıldı. Vaginal smear örneklerinde spermatozoon bulunan ve vaginal plak şekillenen dişiler gebeliğin 1 . gününde kabul edildi (17). Gebeliğin 7., 14. ve 21. gününde, doğumdan sonraki 7.günde (laktasyon dönemi) ve sütten kesildikten sonraki 7. günde (involüsyon periyodu) Ketalar (Ketamin $\mathrm{HCl}$ - Phizer) $(90 \mathrm{mg} / \mathrm{kg}$ ) anestezisi altında; abdominal bölgedeki memenin iki tanesi total olarak çıkarıldı. Deney hayvanları post-operatif bakıma alındı. Gruplardan alınan meme dokuları \% 10 nötral formalin solüsyonunda 24 saat tespit edildi. Daha sonra rutin histolojik takip işlemlerinden geçirilip paraplastta bloklandı. Elde edilen parafin bloklarından, Leica RM 2125 Rotary mikrotomunda 5 mikron kalınlığında seri kesitler 3-aminopropyl-triethoxysilane (APES) ile kaplanmış lamlara alındı.

\section{İmmunohistokimyasal Boyama}

Adesivli lamlara alınan kesitlere streptavidin peroksidaz immunohistokimya yöntemi uygulandı. Bu işlem için öncelikle kesitler deparafinizasyon ve rehidrasyon işlemlerine tabi tutuldu ve ardından distile suda çalkalandı. Endojen peroksidaz aktivitesini gidermek için kesitler \%3 lük H2O2 ile 20 dk muamele edilip 0.01 M Fosfat Buffer Saline ile iki kez $5 \mathrm{dk}$ yıkandı. Bloking serumda $15 \mathrm{dk}$ muamele edilen kesitler ghrelin (abcam, ab129383), obestatin (abcam, ab41704) ve leptin (abcam, ab117751) tavşan poliklonal primer antikorları ile +4 으 C de 1 gece inkübe edildi. Sonrasında $0.01 \mathrm{M} \mathrm{PBS}$ 'te $4 \mathrm{kez}$ yıkanıp biotinlenmiş sekonder antikor (Histostain Plus Bulk Kit, Zymed) ile $20 \mathrm{dk}$ nem odasında inkübe edilerek 4 kez PBS ile yıkanıp, enzim konjugatlı strepavidinde (Histostain Plus Bulk Kit, Zymed) 20 dakika muamele edildi. Kesitler 4 kez PBS ile yıkandıktan sonra Diaminobenzidine (DAB) kromojen solüsyonunda 10-15 dk bekletilerek, Gill hematoksileninde $1 \mathrm{dk}$ süreyle zıt boyamadan sonra çeşme suyunda yıkandı. Yıkanan kesitler alkol ve ksilol serilerinden geçirilip entellan ile kapatıldı. Boyanan preparatlar Nikon-Eclipse E400' de DS-RI1 video kamera (Nikon) ataçmanlı mikroskopta incelenerek fotoğraflandı.

\section{Yarı Kantitatif Değerlendirilme}

Leptin, ghrelin ve obestatin immünoreaktiviteleri, boyamanın yoğunluğuna dayalı yarı kantitatif skorlama yöntemi kullanılarak ölçüldü (18). Bu yöntemde immunohistokimyasal skorlama (-) negatif; (+) zayıf; (++) orta veya (+++) güçlü olarak değerlendirildi. Hücrelerde pozitif immunoreaksiyonların değerlendirilmeleri iki bağımsız araştırmacı tarafından yapıldı (BGS ve HS) ve ortalama skorlar hesaplandı. Meme bezinde leptin, ghrelin ve obestatin ifadeleri mikroskobik olarak $x 40, x 100$, x200 ve x400 büyütmede değerlendirildi. Sonuçlar, meme alveol ve kanal epitel hücreleri, bağdoku, yağ ve miyoepitel hücreleri için ayrı ayrı değerlendirildi ve sunuldu (Tablo 1 ). 
Tablo 1. Meme Dokusunda Ghrelin, Obestatin ve Leptin İmmunoreaktivite Yoğunluğu

\begin{tabular}{|c|c|c|c|c|}
\hline \multirow[t]{2}{*}{ Dönemler } & \multirow{2}{*}{ Meme Bezinin Bölümleri } & \multicolumn{3}{|c|}{ Metabolik Hormonlar } \\
\hline & & Ghrelin & Obestatin & Leptin \\
\hline \multirow{5}{*}{ Gebelik 1. Dönem } & Alveol epiteli & + & +++ & +++ \\
\hline & Kanal epiteli & + & +++ & +++ \\
\hline & Bağdoku hücresi & ++ & - & +++ \\
\hline & Yağ hücresi & - & - & +++ \\
\hline & Miyoepitel & - & - & ++ \\
\hline \multirow{4}{*}{ Gebelik 2. Dönem } & Kanal epit. & ++ & +++ & +++ \\
\hline & Bağdoku hüc. & + & - & +++ \\
\hline & Yağ hücresi & - & - & +++ \\
\hline & Miyoepitel & - & - & ++ \\
\hline \multirow{5}{*}{ Gebelik 3. Dönem } & Alveol epit. & ++ & +++ & +++ \\
\hline & Kanal epit. & ++ & +++ & +++ \\
\hline & Bağdoku hücre. & + & - & +++ \\
\hline & Yağ hücresi & - & - & +++ \\
\hline & Miyoepitel & - & - & ++ \\
\hline \multirow{5}{*}{ Laktasyon } & Alveol epit. & +++ & +++ & +++ \\
\hline & Kanal epit. & +++ & +++ & +++ \\
\hline & Bağdoku hücre. & + & - & +++ \\
\hline & Yağ hücresi & - & - & +++ \\
\hline & Miyoepitel & - & - & ++ \\
\hline \multirow{5}{*}{ İnvolüsyon } & Alveol epit. & + & ++ & +++ \\
\hline & Kanal epit. & + & ++ & +++ \\
\hline & Bağdoku hücre. & - & - & +++ \\
\hline & Yağ hücresi & - & - & +++ \\
\hline & Miyoepitel & - & - & ++ \\
\hline
\end{tabular}

\section{BULGULAR}

Bütün gruplar için kullanılan negatif kontrollerde immunreaksiyon görülmedi (Şekil 1). Ghrelin immunreaksiyonunun alveol ve kanal epitel hücrelerinde gebeliğin 1.döneminde zayıf (Şekil 2A), 2. ve 3. dönemlerinde orta derecede (Şekil $2 B, C$ ), laktasyon periyodunda ise güçlü olduğu belirlendi (Şe-

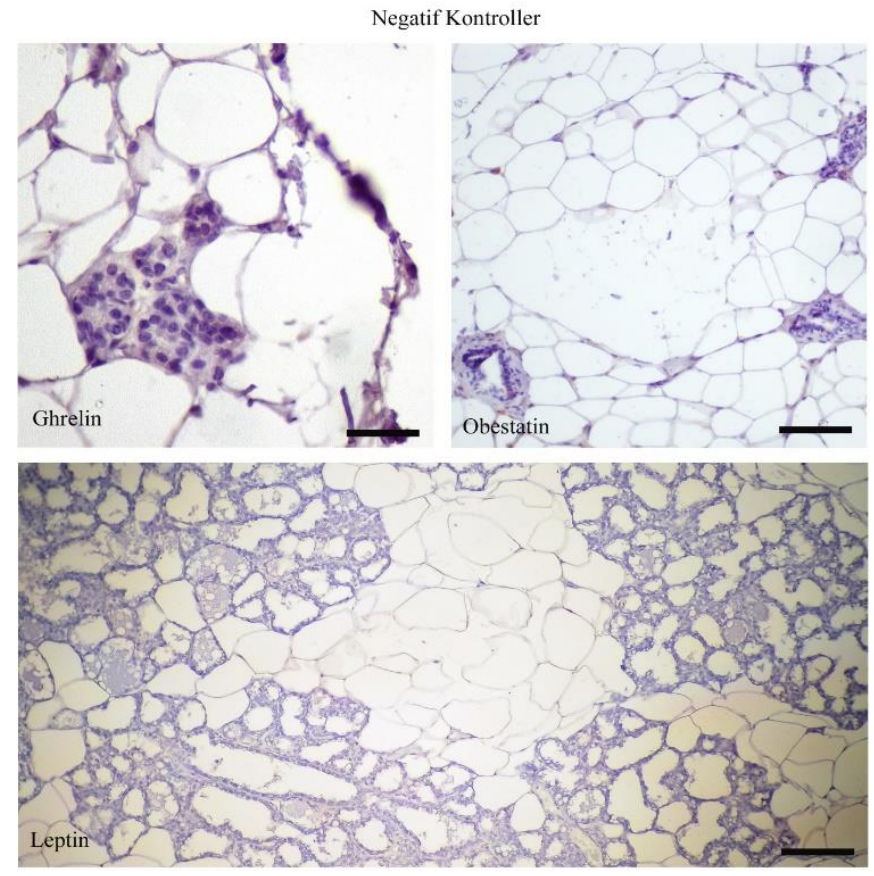

Şekil 1. Ghrelin, obestatin ve leptin için negatif kontroller. Bar: A, B; $25 \mu \mathrm{m} ; \mathrm{C} ; 100 \mu \mathrm{m}$. kil 2D). İnvolusyon periyodunda da ghrelin immunreaksiyonunun zayıfladığı izlendi (Şekil $2 E$ ). İncelenen tüm periyodlarda bazı bağdoku hücrelerinde ghrelin immunreaksiyonunun değişkenlik gösterdiği, yağ ve miyoepitel hücrelerinin ise bulunmadığı tespit edilmiştir.

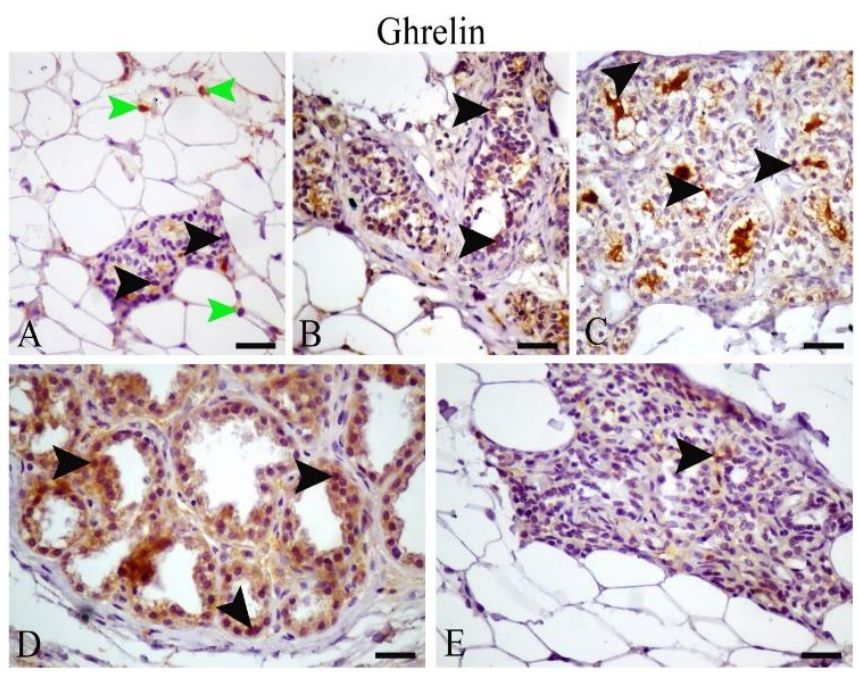

Şekil 2. Meme dokusunda Ghrelin immünohistokimyasal ekspresyonu. (A) gebeliğin 1. döneminde alveol ve kanal epitelinde zayıf boyanma (siyah ok başı), bağdoku hücrelerinde boyanma (yeşil ok başı). (B, C) gebeliğin 2. ve 3.dönemlerinde orta derecede boyanma (alveol ve kanal epitelinde boyanma siyah ok başı, (D) laktasyon döneminde yoğun boyanma (siyah ok başı), (E) involusyon periyodunda zayıf boyanma (siyah ok başı). Bar: $25 \mu \mathrm{m}$. 
Gebelik ve laktasyon periyodlarında obestatin immunreaksiyonu alveol ve kanal epitel hücrelerinde güçlü idi (Şekil $3 A-D)$. Involusyon periyodunda ise immunreaksiyon yoğunluğunun orta derecede olduğu dikkat çekti (Şekil 3E). Tüm periyodlarda bağdoku ve miyoepitel hücrelerinde immunreaksiyon olmadığı izlendi.

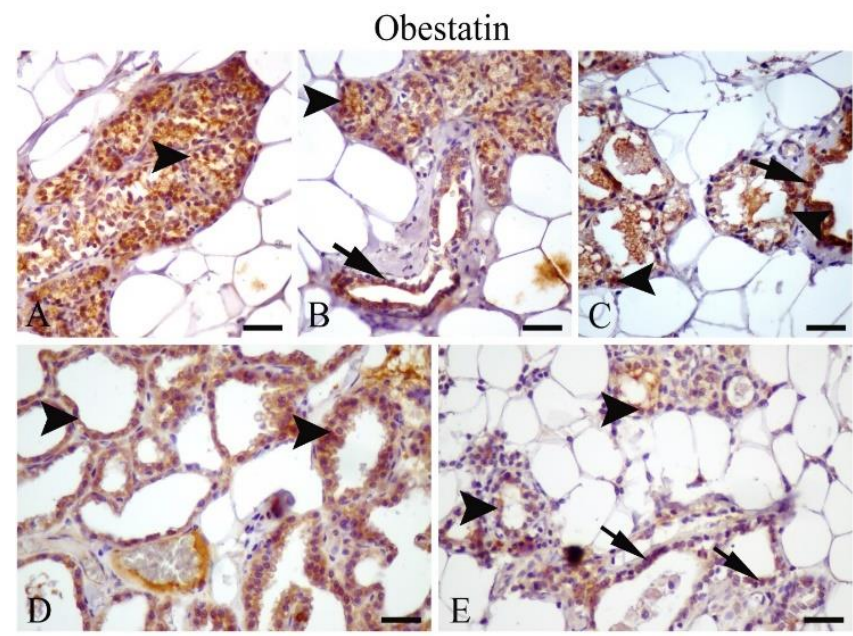

Şekil 3. Meme dokusunda Obestatin immünohistokimyasal ekspresyonu. (A, B, C, D) gebeliğin 1. 2. 3. ve laktasyon dönemlerinde alveol (siyah ok başı) ve kanal epitelinde (siyah ok) güçlü boyanma, (E) involusyon periyodunda zayıf boyanma. Bar: A-D $25 \mu \mathrm{m}, \mathrm{E} ; 50$ $\mu \mathrm{m}$.

\section{TARTIŞMA VE SONUÇ}

Meme bezinin gelişimi, çeşitli hormonal ve moleküler maddeler aracılığı ile başlayan alveol ve kanal epitel hücrelerinin çoğalmasını ve farklılaşmasını kapsayan bir süreçtir (19). Bizim çalışmamızda, meme bezi gelişim sürecinde rolleri olabileceğini düşündüğümüz peptit hormonlarından ghrelin, obestatin ve leptinin meme bezi alveol ve kanal epitel hücreleri ile bağdoku ve miyoepitel hücrelerindeki lokalizasyonları ve hücresel dağılımlarının gösterilmesi amaçlanmıştır.

Ghrelin ilk kez mideden izole edilmiş olsa da, memeli, kuş, amfibi ve balık gibi birçok omurgalı türün farklı doku ve organlarından eksprese edildiği ortaya konulmuştur (20). Birçok türde böylesine farklı doku ve organlarda varlığı ortaya konulan gherilinin, çeşitli fizyolojik işlevleri yerine getirdiği düşüncesi oluşmuştur. Bazı çalışmalarda, büyüme hormonu, gıda alımı, karbonhidrat metabolizması, gastrointestinal sistem, kardiyovasküler sistem, hücre proliferasyonu ve reprodüktif sistem üzerine olan etkileri ortaya konulmuştur $(20$, 21). Son yıllardaki çalışmalarda, ghrelinin meme bezi gelişimi ve fonksiyonlarının düzenlenmesinde de önemli roller oynadığı gösterilmiştir (22-25). Kierson ve ark. (25) anne sütündeki ghrelin'nin meme bezinden salındığı sonucuna ulaşmışlardır (25). Keçilerde ghrelinin meme bezlerinin alveol ve kanal epitel hücrelerinde gebeliğin 30 . ve 60 . günlerinde zayıf, 90 . ve 120. günlerinde ise güçlü immunreaksiyon gösterdiği belirtilmiştir (23). Sunulan çalışmada da, keçilerdekine benzer şekilde (23), ghrelinin sıçanlarda gebeliğin 7. gününde alveol ve kanal epitel hücrelerinde zayıf, 14. ve 21. günlerde ise güçlü olduğu ortaya konulmuştur. Ayrıca insanlarda belirtildiği gibi $(22,24,25)$ sıçanlarda laktasyon periyodunda
Leptin immunreaksiyonu gebeliğin tüm dönemlerinde, laktasyon ve involüsyon periyodlarında alveol ve kanal epitel hücrelerinde güçlüydü (Şekil 4A-E). Bağ dokusunda bulunan bazı hücrelerde leptin immunreaksiyonu gebeliğin her üç döneminde, laktasyon ve involusyon periyodunda güçlü, miyoepitel hücrelerinde ise orta derecede olduğu belirlenmiştir.

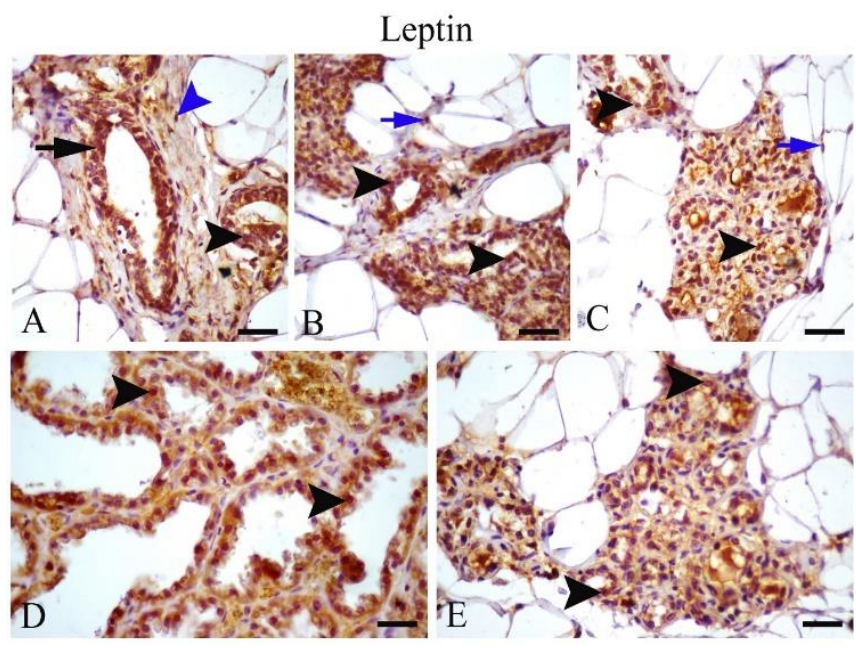

Şekil 4. Meme dokusunda Leptin immünohistokimyasal ekspresyonu. (A, B, C, D) gebeliğin 1. 2. 3. ve laktasyon dönemlerinde alveol (siyah ok başı) ve kanal epitelinde (siyah ok), bağdoku (mavi ok başı) ve yağ hücrelerinde (mavi ok) güçlü boyanma. Bar: $25 \mu \mathrm{m}$.

alveol ve kanal epitel hücrelerinin güçlü bir ghrelin immunreaksiyonu gösterdiği ortaya konulmuştur. Bizim çalışmamızda, sıçanlarda involüsyon periyodunda ghrelin immunreaksiyonunun zayıfladığı, tüm periyodlarda bazı bağ doku hücrelerinin sadece immunreaksiyon gösterdiği de saptanmıştır. Yukarıda bahsedildiği gibi (21-25) çalışmamızdaki mevcut bulgulara göre sıçanlarda da, ghrelinin gebelik sırasında meme büyümesinde ve gelişiminde önemli bir rol oynayabileceği düşünülmüştür. Çalışmamızda gebeliğin erken evresinde ghrelinin zayıf immunreaksiyonunun, gebeliğin sonuna doğru ve laktasyon periyodlarında artması muhtemelen meme bezinde fizyolojik olarak enerji dengesinin düzenlenmesinde ghrelinin etkin olabileceği hipotezini düşündürmüştür.

Obestatin, kemirgenlerde ve insanlarda metabolik fonksiyonların düzenlenmesinde rol oynayan gastrointestinal bir peptittir (26). Obestatin'in vücuttaki fonksiyonları hala tartışmalıdır. Özellikle, tokluk hissini uyararak ve dolayısıyla yiyecek alımını azaltarak ghreline karşı rol oynadığı bildirilmiştir. Ancak bu hipotez ilgili tartışmalar halen devam etmektedir $(8,13,26)$. Son yıllarda, obestatinin adiposit fonksiyonlarını ve glükoz metabolizmasını düzenlemeyi içeren metabolik rollere sahip olabileceği de gösterilmiştir. Ayrıca, ghrelin/obestatin dengesinin vücut enerji homeostazının düzenlenmesi ve besin yetersizliği durumlarına organizmayı adapte etmek gibi fizyolojik fonksiyonları da yerine getirmekte önemli olduğu gösterilmiştir $(8,26)$. Son yıllarda yapılan çalışmalarda, obestatinin ekspresse olduğu hücrelerin proliferasyonunu ve hayatta kalma sürelerini de etkilediği ortaya konulmuştur $(26,27)$. Grönberg ve ark (27)'de insanlarda 
meme bezinden obestatinin alveol epitel hücrelerinden zayıf, kanal epitel hücrelerinden ise orta yoğunlukta bir ekspresyon gösterdiğini ortaya koymuşlardır. İnsan meme bezinde obestatin varlığını da bu peptit hormonun parakrin yolla etki ederek, dolaşımdaki seviyelerini etkileyebileceği şeklinde yorumlamışlardır (27). İnsanlarda bildirildiği gibi (27), bizim çalışmamızda da sıçan meme bezinde gebelik, laktasyon ve involüsyon periyodlarında obestatin immunreaksiyonun alveol ve kanal epitel hücrelerinde bulunduğu ancak immunreaksiyonun gebelik ve laktasyonda güçlü, involüsyon periyodunda ise orta yoğunlukta olduğu gözlenmiştir. Ayrıca, insanlardakine benzer şekilde (27), sıçanlarda da tüm periyodlarda bağdoku ve miyoepitel hücrelerinde obestatin immunreaksiyonunun bulunmadığı tespit edilmiştir. Sıçan meme bezinde gebelik, laktasyon ve involüsyon periyodları süresince obestatinin alveol ve kanal epitel hücrelerinde farklı immunreaksiyonlar göstermesi, obestatinin sıçan meme bezinde de yukarıda bahsedilen fonksiyonları yerine getiriyor olabileciğini düşündürmüştür.

Obezite geninin 167 aminoasitli hormonal proteini olan leptin, polipeptid ve tek zincirli yapıda bir hormondur. Leptin' in üretim yeri öncelikli olarak beyaz yağ doku ve az miktarda kahverengi yağ dokudur $(14,28)$. Leptin canlılarda iştah, enerji dengesi, böbrek ve endokrin bez fonksiyonların düzenlenmesi, üreme, bağışıklık, hematopoez, anjiyogenezis ve yara iyileşmesinin yanı sıra hücre farklılaşması ve proliferasyonu gibi önemli fizyolojik işlevlerde de görev aldığı bildirilmiştir $(28,29)$. Genç farelerde meme bezinde leptinin yağ hücrelerinde yoğun miktarda lokalize olduğu, gebelik ile birlikte farelerde meme kanalları dallanmaya başlayıp, memede yağ dokusu azaldığında leptinin alveol ve kanal epitel hücrelerinde ağırlıklı olarak lokalize olduğu ortaya konulmuştur (29). Insan meme alveol ve kanal epitel hücrelerinde leptinin ekspresse olduğu ve özelliklede laktasyon döneminde ekspresyonun güçlü olduğu saptanmıştır (14). Yapılan çalışmalarda laktasyon dönemindeki kadın, fare, koyun, inek ve keçilerin meme bezi epitel hücrelerinde leptin varlığı bildirilmiştir $(14,28,29,30)$. Ayrıca gebeliğin erken ve geç dönemleriyle (özellikle doğumdan hemen önce), laktasyon döneminde epitel ve miyoepitelyal hücrelerinde leptin ekspresyonu gösterilmiştir $(28,29)$. Bizim çalışmamızda da, sıçan meme bezi alveola ve kanal epitel hücreleri ile stromal ve miyoepitel hücrelerinde gebelik, laktasyon ve involüsyon periyodlarında farklı yoğunluklarda leptin ekspresyonları gösterilmiştir. Böylelikle leptin'nin meme bezi alveal ve kanal epitel hücrelerinin proliferasyonunu ve farklılaşmasını indüklediğini ifade edebiliriz. Daha önceki yapılan çalışmalardakine benzer şekilde $(14,28,29,30,31)$, sıçanlarda da meme bezindeki yağ hücreleri, epitel ve miyoepitel hücreleri tarafından leptin üretildiğini söyleyebiliriz.

İnsan, fare, sıçan, tavşan, sığır ve koyunların meme bezi de dahil olmak üzere çeşitli doku ve organlarında ghrelin, obestatin ve leptinin stromal ve miyoepitelyal hücreleri, ganglion nöronları ve sinir pleksuslarından eksprese edildiği bildirilmiştir (19). Bizim çalışmamızda da, sıçan meme bezindeki miyoepitel ve stromal (özellikle yağ hücreleri) hücrelerde ghrelin ve obestatin immunreaksiyonun negatif, leptin immunreaksiyonun ise pozitif olduğu tespit edilmiştir.
Leptinin farklı hücre türlerinde üretilmesinin nöral uyarılar ve stromal-yağ-epitel hücre etkileşimleri yoluyla hücre büyümesi ve farklılaşmasının uyarılması ile enerji dengesinin sağlanması gibi çeşitli vücut fonksiyonlarında parakrin faktör olarak etki ettiği ifade edilmiştir $(30,31)$. Bizim çalışmamızda da benzer bulguların olması sıçan meme bezinde de yukarıda bahsedilen benzer fonksiyonlarda leptinin görev aldığını düşündürmüştür.

Sonuç olarak, sıçanlarda meme bezinde gebelik, laktasyon ve involüsyon periyodlarında ghrelin, obestatin ve leptinin alveol ve kanal epitel hücrelerinde farklı yoğunluklarda lokalize olduğunu belirledik. Ayrıca, bazı stramol ve miyoepitel hücrelerinde gherilin ve obestatinin lokalize olmadığını, leptinin ise lokalize olduğunu gösterdik. Bu durumda, sıçanlarda meme bezinin bu peptit hormonların kaynağı olduğunu söyleyebiliriz. Ayrıca, gebelik, laktasyon ve involüsyon periyodlarında alveol ve kanal epitel hücrelerinin farklılaşması ve canlılık sürelerinin uzatılmasında da gherilin, obestatin ve leptinin rol oynayabileceğini de ifade edebiliriz.

\section{TEŞEKKÜR}

Bu çalışma Dicle Üniversitesi Bilimsel Araştırma Projeleri Koordinatörlüğü tarafından VETERINER.15.001 numaralı proje ile desteklenmiştir. Bu çalışmada kullanılan meme bezi örnekleri "Sıçanların Meme Dokusunda Gebelik, Laktasyon ve Laktasyon Sonrası Dönemde Epidermal Büyüme Faktörü (EGFR) ve Vasküler Epidermal Büyüme Faktörü Reseptörlerinin (VGFR) Dağılımınının Immunohistokimyasal Olarak Gösterilmesi" başlıklı ve 2008/01 numaralı projeden alınmıştır.

\section{KAYNAKLAR}

1. Kul E, Erdem H, Atasever S. (2006). Süt Sığırlarında Farklı Meme Özelliklerinin Mastitis ve Süt Somatik Hücre Sayısı Üzerine Etkileri. OMÜ Ziraat Fak Derg. 21(3): 350-356.

2. Reece WO. (2004). Physiology of Domestic Animals. Newyork/USA, Cornell University press. 710-711.

3. Hurley WL. (2008). "Mammary Development-postpubertal". http:// www. classes ansci. edu. Erişim Tarihi: 27.03.2020

4. Solaman D. (2008). "Biology of the Mammary Gland". http:// www. mammary. nih. gov. Erişim Tarihi: 27.03.2020

5. Wolinski J, Słupecka M, Romanowicz K. (2014). Leptin and Ghrelin Levels in Colostrum, Milk and Blood Plasma of Sows and Pig Neonates During the First Week of Lactation. Anim Sci J. 85: 143-149.

6. Suleyman A, Yusuf O, Fazilet E, Bilgin G, Nermin K. (2008). Presence of Obestatin in Breast Milk: Relationship Among Obestatin Ghrelin, and Leptin in Lactating Women. Nutrition. 24: 689693.

7. Grönberg M, Fjällskog ML, Jirström K, Janson ET. (2012). Expression of Ghrelin is Correlated to A Favorable Outcome in Invasive Breast Cancer. Acta Oncol. 51: 386-393.

8. Çetin F, Aygün C, Erman F, Aydın S. (2009). Fonksiyonel Dispepside Obestatin ve Ghrelinin Rolü. Akademik Gastroenteroloji Derg. 8(3): 102-107.

9. Filgo AJ, Foley JF, Puvanesarajah S, Borde AR. (2016). Mammary Gland Evaluation in Juvenile Toxicity Studies: Temporal Developmental Patterns in the Male and Female Harlan SpragueDawley Rat. Toxicol Pathol. 44(7): 1034-1058. 
10. Nakahara K, Hayashida T, Nakazato M, Kojima M. (2003). Effect of Chronic Treatments with Ghrelin on Milk Secretion in Lactating Rats. Biochem Biophys Res Commun. 303: 751-755.

11. Bilgin HM. (2006). Ghrelin, Gündemdeki Hormon. Dicle Tıp Derg. 33(4): 268-272.

12. Dayangaç A. (2006). Ghrelin Hormonu ve Biyolojik Aktiviteleri. DAUM. 4(2): 62-68.

13. Vicennati V, Genghini, S, lasio De R, Pasqui F. (2007). Circulating Obestatin Levels and The Ghrelin/Obestatin Ratio in Obese Women. Eur J Endocrinol. 157: 295-301.

14. Zhang Y, Proenca R, Maffei M, et al. (1994). Positional cloning of the mouse obese gene and its human homologue. Nature. 372: 425-432.

15. Yiş U, Öztürk Y, Büyükgebiz B. (2005). Ghrelin: Enerji Metabolizmasının Düzenlenmesinde Yeni Bir Hormon. Çocuk Sağlığı ve Hastalıkları Dergisi. 48: 196-201.

16. Susan M, Kırwin S, O’Connor DM, Johnston J. (2015). Leptin Expression in Human Mamamary Epithelial Cells and Breast Milk. J Clin Endocrinol Metab. 83(5):1810-1813.

17. Hovey RC, Goldhar AS, Baffi J. et al. (2001). Transcriptional Regulation of Vascular Endothelial Growth Factor Expression in Epithelial and Stromal Cells during Mouse Mammary Gland Development. Mol Endocrinol. 15: 819-831.

18. Sağsöz H, Erdoğan S, Saruhan B G. (2020). The Expressions of Some Metabolic Hormones (Leptin, Ghrelin and Obestatin) in the Tissues of Sheep Tongue. Anat Histol Embryol. 49: 112-120.

19. Muriel Bonnet, Carole Delavaud, Karine Laud, et al. (2002). Mammary Leptin Synthesis, Milk Leptin and Their Putative Physiological Roles. Reprod Nutr Dev. 42: 399-413.

20. Litwiniec A, M. Izdebska, R. Włodarczyk, A. Grzanka, J.M. Jaśkowski. (2008). Ghrelin-Characterization, Regulation of Synthesis, Release and Possible Role in Reproduction. J Anim Feed Sci. 17: 455-472.

21. Illhan T, Erdost H. (2009). Ghrelin. Uludag Univ J Fac Vet Med. 28(1): 67-74.

22. Cesur G, Özgüner MF, Öngel K. (2009). Ghrelin ile Adiponektin Hormonları ve Büyüme Üzerine Etkileri. Medical Sci. 4(4):105117.
23. Zhang W, Zhang Z, Chen J, Tong D. (2018). Ghrelin is Expressed in the Pregnant Mammary Glands of Dairy Goats and Promotes the Cell Proliferation of Mammary Epithelial Cells. Gen Comp Endocrinol. 260: 115-124.

24. Gnanapavan S, Kola B, Bustin SA. et al. (2002). The Tissue Distribution of the mRNA of Ghrelin and Subtypes of Its Receptor, GHS-R, in Humans. J Clin Endocrinol Metab. 87: 2988-2991.

25. Kierson JA, Dimatteo DM, Locke RG, Mackley AB, Spear ML, (2006). Ghrelin and Cholecystokinin in Term and Preterm Human Breast Milk. Acta Paediatr. 95(8):991-995.

26. Slupecka MS, Romanowicz K, Wolinski J. (2016). Maternal HighFat Diet During Pregnancy and Lactation Influences Obestatin and Ghrelin Concentrations in Milk and Plasma of Wistar Rat Dams and Their Offspring. Int J Endocrinol. 1-9.

27. Grönberg M, Apostolos VT, Magnusson L, Janson ET. (2008) Distribution of Obestatin and Ghrelin in Human Tissues: Immunoreactive Cells in the Gastrointestinal Tract, Pancreas and Mammary Glands. J Histochem Cytochem. 56(9): 793-801.

28. Bonnet M, Gourdou I, Leroux C, Chilliard Y. (2002). Leptin Expression in the Ovine Mammary Gland: Putative Sequential Involvement of Adipose, Epithelial, and Myoepithelial Cells During Pregnancy and Lactation. J Anim Sci. 80: 723-728.

29. Chilliarda Y, Bonneta M, Delavauda C, et al. (2001). Leptin in Ruminants. Gene Expression in Adipose Tissue and Mammary Gland, and Regulation of Plasma Concentration. Domest Anim Endocrinol. 21: 271-295.

30. Denis RGP, Williams G, Vernon RG. (2003). Regulation of Serum Leptin and Its Role in the Hyperphagia of Lactation in the Rat. J Endocrinol. 176: 193-203.

31. Lin Ye, Zhang LIQ. (2007). Expression and Function of Leptin and Its Receptor in Mouse Mammary Gland. Sci China Ser C: Life Sci. 50 (5): 669-675.

\section{Sorumlu Yazar:}

Berna GÜNEY SARUHAN

Dicle Üniversitesi, Veteriner Fakültesi, Histoloji-Embriyoloji Anabilim Dalı, Diyarbakır, TÜRKIYE

E-mail: bsaruhan@dicle.edu.tr 